\title{
Life table and age-dependent reproduction of the predatory bug Orius niger Wolff (Heteroptera: Anthocoridae) at three constant temperatures: a demographic analysis
}

\author{
Valiollah BANIAMERI, ${ }^{1}{ }^{*}$ Ebrahim Soleiman-NEJAdiAN ${ }^{2}$ and Jafar MOHAGHEgH ${ }^{1}$ \\ ${ }^{1}$ Plant Pests and Diseases Research Institute (PPDRI); Tehran, Iran \\ ${ }^{2}$ Plant Protection Dept., College of Agriculture, Sh. Chamran University; Ahwaz, Iran \\ (Received 23 July 2004; Accepted 14 May 2005)
}

\begin{abstract}
The predatory bug Orius niger Wolff occurs throughout Iran in various climatic zones. Because of its apparent adaptation to these different climates, it is being considered as a potential biological control agent of the pest Thrips tabaci Lind. in various crops in Iran. We measured the basic life-history parameters of $O$. niger on a diet of corn pollen and eggs of the moth Ephestia kuehniella Zeller at 3 constant temperatures $\left(26,29\right.$ and $32^{\circ} \mathrm{C}$ under $\left.16 \mathrm{~L}-8 \mathrm{D}\right)$ to assess the possibility of culturing this predator for mass releases. Bean pods were supplied as oviposition sites. The intrinsic rate of increase was $0.113,0.127$ and 0.157 daughters/female/day at 26,29 , and $32^{\circ} \mathrm{C}$ respectively. Analysis of the mortality of eggs, juveniles and adults suggests that the population growth rate is restricted most by juvenile mortality. This mortality is probably caused by cannibalism, the occurrence of which should therefore be minimized in mass cultures.
\end{abstract}

Key words: Biological control; Orius niger; thrips; mass cultures; intrinsic rate of increase

\section{INTRODUCTION}

In recent years, the use of predatory bugs of the genus Orius as biological control agents of thrips like Frankliniella occidentalis Pergande and Thrips tabaci Lind. has greatly increased in many greenhouse vegetables and ornamental crops (Van den Meiracker and Ramakers, 1991; Van de Veire and Degheele, 1992; Cocuzza et al., 1997; Van den Meiracker, 1999). Orius consists of 67 species (Yasunaga, 1997) and Orius niger Wolff is a Palaearctic species (Loomans et al., 1995) and has been recorded from many parts of Iran. This species preys upon thrips (Ramakers, 1978), mites and aphids (Akramovskaya, 1978), eggs and larvae of Lepidoptera, and eggs of pentatomids (Pericart, 1972). The species is commonly found attacking $T$. tabaci throughout Iran, suggesting that it is adapted to the diverse climatic conditions of this country. Although this would make the species ideally suited for biological control of thrips in Iran, it has not yet been studied extensively.

Thrips tabaci is an important pest of greenhouse crops in Iran and many other countries. It causes crop damage directly by feeding on parenchyma and puncturing the plant tissue for oviposition, resulting in a reduction of the photosynthetic capacity (Royer et al., 1986; Van Rijn, 2002) and indirectly by transmission of plant viruses such as the TSWV (Tomato Spotted Wilt Virus) (Broadbent et al., 1987; German et al., 1992).

Demography is a powerful tool to study natural enemies that must be reared on a large scale in order to optimise rearing conditions. Although this method has been used extensively in studying populations of plant pests and their natural enemies (Carey, 1982; Carey and Vargas, 1985; Liedo and Carey, 1994), there are limited literatures on estimating the biologic and reproductive parameters of O. niger. Van den Meiracker (1999) used the demographic analysis to optimise the mass rearing of $O$. niger.

Since Orius species are polyphagous predators, they can be reared on different types of prey. For example, eggs of Sitotroga cerealella Oliveir have been used for Orius minutus Neimczyk, eggs of

\footnotetext{
* To whom correspondence should be addressed at: E-mail: baniameri@ppdri.ac.ir DOI: $10.1303 /$ aez.2005.545
} 
Mamestra brassicae L. for O. niger (Van de Veire and Degheele, 1992), eggs of Helicoverpa virescens F. for Orius insidiosus Say (Isenhour and Yeargan, 1981), Ephestia kuehniella Zeller for $O$. insidiosus (Fisher et al., 1992; Alauzet et al., 1994).

The objectives of the current study were to determine life table and reproductive parameters such as intrinsic rate of increase, net reproductive rate, mean generation time and oviposition period of $O$. niger in three different temperatures when fed on eggs of E. kuehniella and corn pollen to provide information for mass rearing of the predator.

\section{MATERIALS AND METHODS}

Rearing. Predatory bugs used in the experiments were collected on marguerite flowers Chrysanthemum frutescens L. (Compositae) in Tehran, Iran. O. niger was separated and identified using the single rearing method (Yasunaga and Kashio, 1993; Yasunaga, 1997). They were reared at $26^{\circ} \mathrm{C}$, r.h. $70 \pm 5 \%$ and a photoperiod of L16:D8 hours with eggs of E. kuehniella as food. Green bean pods and corn pollen were used as oviposition sites and supplementary food respectively (See Van den Meiracker, 1994, for details).

Life table and reproduction. Fresh bean pods were placed in rearing jars of $O$. niger for oviposition. After $4 \mathrm{~h}$, the pods with eggs were incubated at 26,29 or $32^{\circ}$ C, r.h. $70 \pm 5 \%$, and L16:D8 in plastic soft drink bottles $(150 \mathrm{ml})$ lined with paper tissue, and closed with a screw cap. Three cohorts of 159,103 and 96 eggs were used at 26, 29 and $32^{\circ} \mathrm{C}$ respectively. Ventilation was through two lateral holes covered with fine nylon mesh. Water was supplied in a small glass test tube closed with cotton wool. E. kuehniella eggs were provided for nymphs and adults on a small piece of paper which was replaced every day. Bottles were checked daily for egg hatching, nymphal survival and adult eclosion. A total of 30 eclosed females at $26^{\circ} \mathrm{C}$ and 20 females for the two other temperatures were separated and kept individually with 2-3 males in a small test tube for $1 \mathrm{~h}$ to ensure mating. Each mated female plus males were transferred to a plastic cup $(100 \mathrm{ml})$ with lid and two lateral holes covered with mesh to provide ventilation. The bugs were daily provided with fresh E. kuehniella eggs and corn pollen and a piece of bean pod $(2 \mathrm{~cm})$ as food and oviposition sites respectively. Bean pods were checked daily for Orius eggs and were kept in vials until hatching. Survival of eggs was recorded after the hatching of all of the eggs. To prevent disturbance of nymphs, their survival and sex were recorded at the emerging of the adults.

\section{RESULTS}

The basic life table of $O$. niger at different temperatures is given in Table 1. The main parameters in a life table are $l_{x}$ (proportion of females surviving to start of age interval $x$ ) and $m_{x}$ (average number of female eggs laid by a female of age $x$ ). The most basic measure of reproduction is the average number of eggs laid by a female in the cohort in the interval $x$ to $x+1$ and is denoted $M_{x}$ (Table 1). The fraction of these eggs that hatch represents the hatch schedule, $h_{x}$ (Table 1). We followed the methods of Birch (1948), Andrewartha and Birch (1954) and Carey (1993) for calculating life table parameters and reproductive parameters from this reference. Net reproductive rate $\left(R_{0}\right)$, intrinsic rate of increase $\left(r_{m}\right)$, finite rate of increase $(\lambda)$, intrinsic birth rate $(b)$, intrinsic death rate $(d)$, doubling time $(D T)$ and mean generation time $(T)$ were calculated using the formulae shown in Table 2.

The estimates of reproductive parameters with their formulae and units are also shown in Table 2. These statistics show that females are expected to lay a total of 76.7 eggs and 60.7 fertile eggs at $26^{\circ} \mathrm{C}$. The net fecundity rate is 71.9 eggs and the net fertility rate is 57.1 fertile eggs. This suggests that egg mortality alone reduced potential reproduction by approximately 0.20 at $26^{\circ} \mathrm{C}(=1-$ fertile eggs/total eggs), female mortality alone reduced potential reproduction by approximately 0.06 (=1-net fecundity/gross fecundity, see Carey, 1993) and the combination of egg mortality and female mortality reduced potential reproduction by 0.25 (Table 3 ). For 29 and $32^{\circ} \mathrm{C}$, these values are given in Table 3.

Orius niger females start ovipositing 5.08 \pm 0.99 (SD) days after they became mature and oviposited on average for $14.5 \pm 3.11$ (SD) days at $26^{\circ} \mathrm{C}$ (Fig. 1a). At $29^{\circ} \mathrm{C}$ and $32^{\circ} \mathrm{C}$, oviposition started at $5.06 \pm 1.6$ days and $3.57 \pm 0.57$ days respectively (Fig. 1b, c). The average number of eggs laid by a female per day was 2.84 at $26^{\circ} \mathrm{C}, 4.29$ at $29^{\circ} \mathrm{C}$ and 5.55 at $32^{\circ} \mathrm{C}$. Generally, the average number of 
Table 1. Basic life-history measurements of Orius niger on a diet of corn pollen and eggs of E. kuehniella at 3 different temperatures. $x=$ age of female in days; $l_{x}=$ survival of female until $x ; m_{x}=$ number of female offspring produced at age $x$; $M_{x}=$ total number of offspring (=number of eggs) produced at age $x, h_{x}=$ hatch rate of eggs.

\begin{tabular}{|c|c|c|c|c|c|c|c|c|c|c|c|c|c|c|}
\hline \multicolumn{5}{|c|}{$26^{\circ} \mathrm{C}$} & \multicolumn{5}{|c|}{$29^{\circ} \mathrm{C}$} & \multicolumn{5}{|c|}{$32^{\circ} \mathrm{C}$} \\
\hline$x$ & $l_{x}$ & $m_{x}$ & $M_{x}$ & $h_{x}$ & $x$ & $l_{x}$ & $m_{x}$ & $M_{x}$ & $h_{x}$ & $x$ & $l_{x}$ & $m_{x}$ & $M_{x}$ & $h_{x}$ \\
\hline $0-5$ & 1 & 0 & 0 & 0 & $0-4$ & 1 & 0 & 0 & 0 & $0-4$ & 1 & 0 & 0 & 0 \\
\hline $5-16$ & 0.89 & 0 & 0 & 0 & $4-13$ & 0.85 & 0 & 0 & 0 & $4-13$ & 0.83 & 0 & 0 & 0 \\
\hline 17 & 0.56 & 0 & 0 & 0 & 14 & 0.52 & 0 & 0 & 0 & 14 & 0.58 & 0 & 0 & 0 \\
\hline 18 & 0.56 & 0 & 0 & 0 & 15 & 0.52 & 0 & 0 & 0 & 15 & 0.58 & 0 & 0 & 0 \\
\hline 19 & 0.56 & 0 & 0 & 0 & 16 & 0.52 & 0.78 & 1.40 & 0.93 & 16 & 0.58 & 0.81 & 1.55 & 0.84 \\
\hline 20 & 0.56 & 0.94 & 1.60 & 0.79 & 17 & 0.52 & 1.96 & 3.50 & 0.89 & 17 & 0.58 & 4.65 & 8.95 & 0.89 \\
\hline 21 & 0.56 & 2.26 & 3.83 & 0.80 & 18 & 0.52 & 3.92 & 7.00 & 0.93 & 18 & 0.58 & 4.73 & 9.10 & 0.92 \\
\hline 22 & 0.56 & 2.22 & 3.77 & 0.88 & 19 & 0.52 & 3.41 & 6.10 & 0.91 & 19 & 0.58 & 4.52 & 8.70 & 0.94 \\
\hline 23 & 0.56 & 2.36 & 4.00 & 0.88 & 20 & 0.52 & 4.06 & 7.25 & 0.90 & 20 & 0.58 & 4.43 & 8.30 & 0.85 \\
\hline 24 & 0.56 & 2.83 & 4.80 & 0.76 & 21 & 0.52 & 3.58 & 6.40 & 0.95 & 21 & 0.55 & 4.21 & 8.11 & 0.88 \\
\hline 25 & 0.56 & 2.38 & 5.73 & 0.80 & 22 & 0.52 & 4.04 & 7.05 & 0.90 & 22 & 0.55 & 3.65 & 6.84 & 0.92 \\
\hline 26 & 0.56 & 2.48 & 4.20 & 0.87 & 23 & 0.49 & 0.87 & 1.52 & 0.86 & 23 & 0.53 & 3.68 & 6.89 & 0.92 \\
\hline 27 & 0.56 & 3.10 & 5.25 & 0.86 & 24 & 0.46 & 3.88 & 6.55 & 0.91 & 24 & 0.50 & 3.09 & 5.94 & 0.89 \\
\hline 28 & 0.54 & 3.62 & 6.14 & 0.79 & 25 & 0.41 & 4.65 & 8.31 & 0.90 & 25 & 0.47 & 3.47 & 6.47 & 0.81 \\
\hline 29 & 0.54 & 2.18 & 3.69 & 0.86 & 26 & 0.41 & 4.15 & 7.18 & 0.89 & 26 & 0.41 & 3.85 & 6.94 & 0.87 \\
\hline 30 & 0.54 & 3.15 & 5.34 & 0.83 & 27 & 0.39 & 2.61 & 4.66 & 0.80 & 27 & 0.32 & 2.33 & 4.00 & 0.91 \\
\hline 31 & 0.54 & 2.28 & 3.86 & 0.87 & 28 & 0.39 & 1.76 & 2.93 & 0.96 & 28 & 0.23 & 0.99 & 1.64 & 0.83 \\
\hline 32 & 0.54 & 1.89 & 3.21 & 0.64 & 29 & 0.31 & 1.21 & 1.07 & 0.96 & 29 & 0.23 & 0 & 1.65 & 0.90 \\
\hline 33 & 0.52 & 1.99 & 3.38 & 0.63 & 30 & 0.28 & 1.31 & 2.25 & 0.88 & 30 & 0 & 0 & 0 & 0 \\
\hline 34 & 0.50 & 1.71 & 2.89 & 0.82 & 31 & 0.23 & 1.40 & 2.27 & 0.90 & & & & & \\
\hline 35 & 0.48 & 1.16 & 1.96 & 0.67 & 32 & 0.21 & 1.31 & 2.22 & 0.88 & & & & & \\
\hline 36 & 0.48 & 2.16 & 3.65 & 0.65 & 33 & 0 & 0 & 0 & & & & & & \\
\hline 37 & 0.47 & 0.68 & 1.15 & 0.30 & & & & & & & & & & \\
\hline 38 & 0.43 & 0.43 & 0.73 & 0.66 & & & & & & & & & & \\
\hline 39 & 0.41 & 1.08 & 1.82 & 0.63 & & & & & & & & & & \\
\hline 40 & 0.39 & 0.38 & 0.64 & 0.85 & & & & & & & & & & \\
\hline 41 & 0.35 & 0.55 & 0.93 & 0.80 & & & & & & & & & & \\
\hline 42 & 0.32 & 0.34 & 0.57 & 0.91 & & & & & & & & & & \\
\hline 43 & 0.24 & 0.35 & 0.59 & 0.75 & & & & & & & & & & \\
\hline 44 & 0.20 & 0.71 & 1.21 & 0.91 & & & & & & & & & & \\
\hline 45 & 0.17 & 0.11 & 0.18 & 1.00 & & & & & & & & & & \\
\hline 46 & 0.11 & 0.41 & 0.69 & 0.88 & & & & & & & & & & \\
\hline 47 & 0 & 0 & 0 & 0 & & & & & & & & & & \\
\hline
\end{tabular}

eggs laid by a cohort of females increased rapidly during the 4-12 days of the adult life, reaching a maximum of 6.1 eggs on day 12 at $26^{\circ} \mathrm{C}, 8.3$ eggs on day 11 at $29^{\circ} \mathrm{C}$ and 9.1 eggs on day 4 at $32^{\circ} \mathrm{C}$ (Fig. 1). Around $20 \%$ of the females did not oviposit at $26^{\circ} \mathrm{C}, 25 \%$ at $29^{\circ} \mathrm{C}$ and $5 \%$ at $32^{\circ} \mathrm{C}$.

The interpretation of these statistics is that the average reproduction for a cohort that lives to its last day of possible life at $26^{\circ} \mathrm{C}$ (i.e., mean age gross fecundity) is 13.5 days. This mean age is reduced to slightly over 13.2 days by egg mortality alone, but is reduced to around 12.8 days due to adult female mortality alone. For 29 and $32^{\circ} \mathrm{C}$, these values are $9.41,9.37,8.44$, and $10.5,7.5,7.2$ days, respectively. Together, egg mortality and female mortality set the actual mean age of reproduction at 12.5 days at $26^{\circ} \mathrm{C}, 8.4$ days at $29^{\circ} \mathrm{C}$ and 7.2 days at $32^{\circ} \mathrm{C}$. Life expectation at age $0,\left(e_{0}\right)$ was 28.9 days at $26^{\circ} \mathrm{C}, 18.0$ days at $29^{\circ} \mathrm{C}$ and 17.5 days at $32^{\circ} \mathrm{C}$.

\section{DISCUSSION}

There is another study that reports the intrinsic rate of increase of $O$. niger at $25^{\circ} \mathrm{C}$ (Van den Meiracker, 1999). Although others have studied the life history of this species (Tommasini and Nicoli, 1993, 1994), they do not report the intrinsic rate of 
Table 2. Description, symbol, formula, values and units for population parameters of Orius niger

\begin{tabular}{|c|c|c|c|c|}
\hline Parameter & Formula & $26^{\circ} \mathrm{C}$ & $29^{\circ} \mathrm{C}$ & $32^{\circ} \mathrm{C}$ \\
\hline Net reproductive rate (female egg/female) & $R_{0}=\Sigma l_{x} m_{x}$ & 22.95 & 18.62 & 24.42 \\
\hline \multicolumn{5}{|l|}{ Growth rates } \\
\hline Intrinsic growth rate (daughters/female/day) & $1=\sum l_{x} m_{x} e^{-r(x+0.5)}$ & 0.113 & 0.127 & 0.157 \\
\hline Finite rate of increase $\left(\right.$ day $\left.^{-1}\right)$ & $\lambda=e^{r}$ & 1.119 & 1.135 & 1.169 \\
\hline Intrinsic birth rate $\left(\right.$ day $\left.^{-1}\right)$ & $b=\sum e^{-r(x+0.5)} l_{x}$ & 0.129 & 0.152 & 0.180 \\
\hline Intrinsic death rate $\left(\right.$ day $\left.^{-1}\right)$ & $d=b-r$ & 0.016 & 0.025 & 0.023 \\
\hline \multicolumn{5}{|l|}{ Growth times } \\
\hline Doubling time (days) & $D T=(\ln 2) / r$ & 6.1 & 5.5 & 4.4 \\
\hline Mean generation time (days) & $T=\ln R_{0} / r$ & 27.7 & 23.0 & 20.4 \\
\hline \multicolumn{5}{|l|}{ Life time reproductive rates } \\
\hline Gross fecundity rate (eggs/female) & $\Sigma M_{x}$ & 76.7 & 80.8 & 85.1 \\
\hline Gross fertility rate (fertile eggs/female) & $\sum h_{x} M_{x}$ & 60.7 & 73.2 & 75.7 \\
\hline Gross hatch rate (proportion) & $\Sigma h_{x} M_{x} / \Sigma M_{x}$ & 0.79 & 0.90 & 0.88 \\
\hline Net fecundity rate (eggs) & $\sum L_{x} M_{x}$ & 71.9 & 68.6 & 77.5 \\
\hline Net fertility rate (fertile eggs) & $\Sigma L_{x} h_{x} M_{x}$ & 57.1 & 62.2 & 67.7 \\
\hline \multicolumn{5}{|l|}{ Daily reproductive rate } \\
\hline Eggs/female/day & $\Sigma L_{x} M / \Sigma L_{x}$ & 2.8 & 4.3 & 5.6 \\
\hline Fertile eggs/female/day & $\sum L_{x} h_{x} M_{x} / \Sigma^{\prime} L_{x}$ & 2.0 & 3.9 & 4.9 \\
\hline \multicolumn{5}{|l|}{ Mean ages of reproduction } \\
\hline Mean age gross fecundity (days) & $\Sigma x M_{x} / \Sigma M_{x}$ & 13.5 & 9.4 & 10.6 \\
\hline Mean age gross fertility (days) & $\sum x h_{x} M_{x} / \sum h_{x} M_{x}$ & 13.2 & 9.4 & 7.6 \\
\hline Mean age net fecundity (days) & $\Sigma_{x} L_{x} M_{x} / \Sigma L_{x} M$ & 12.8 & 8.4 & 7.2 \\
\hline Mean age net fertility (days) & $\sum x L_{x} h_{x} M_{x} / L_{x} h_{x} M_{x}$ & 12.5 & 8.4 & 7.3 \\
\hline Mean age hatch (days) & $\sum x h_{x} / \sum h_{x}$ & 17.5 & 10.5 & 8.3 \\
\hline
\end{tabular}

Table 3. Reduction of reproduction of Orius niger (as fraction of the potential reproduction) through various mortality factors at three different temperatures

\begin{tabular}{lccc}
\hline Mortality of stage & $26^{\circ} \mathrm{C}$ & $29^{\circ} \mathrm{C}$ & $32^{\circ} \mathrm{C}$ \\
\hline Egg & 0.20 & 0.09 & 0.11 \\
Adult female & 0.06 & 0.15 & 0.08 \\
Combined & 0.25 & 0.23 & 0.20 \\
\hline
\end{tabular}

increase. Our estimate of $r_{m}\left(0.113\right.$ day $\left.^{-1}\right)$ for $O$. niger at $26^{\circ} \mathrm{C}$ is similar to that found by Van den Meiracker (1999) at $25^{\circ} \mathrm{C}$ on a diet of E. kuehniella only $\left(0.118\right.$ day $\left.^{-1}\right)$. However, large differences between the two studies occur for $R_{0}$ and $M_{x}(68.3$ and 166.0 in Van den Meiracker's study and 22.9 and 76.7 in this study, respectively). The similarity of the intrinsic rates of increase of both studies suggests that the differences in reproduction mainly occur later in the reproductive period, where offspring production has a negligible effect on the intrinsic rate of increase.

The advantage of using the intrinsic rate of increase is that it integrates the effects of mortality and fertility factors into a single value. Thus, in- stead of comparing several life history characteristics (i.e., developmental rate, longevity, fertility, mortality, sex ratio) among populations, a single comparison can be applied (Havelka and Zemek, 1999). Sabelis and Van Rijn (1997) based on the literature stated that the $r_{m}$ value for $O$. niger was the lowest among all Orius species studied using $E$. kuehniella as food source. The intrinsic rate of increase can also be used to estimate the effect of the mortality of each stage on the population growth rate, and this can then subsequently be used to optimize mass rearing. Therefore, we recalculated the intrinsic growth rate at $26^{\circ} \mathrm{C}$, assuming that no egg mortality, juvenile mortality or adult mortality would occur. Adult mortality had the lowest effect on the intrinsic growth rate; excluding it resulted in an increase of the $r_{m}$ from 0.113 to 0.114 . Without egg mortality, the $r_{m}$ would be 0.118 , and without juvenile mortality, it would be 0.131 . This suggests that juvenile mortality is the most important factor reducing the growth rate of this species, and this also holds for the other temperatures (Fig. 1b, c). Possibly, this mortality is caused by cannibalism among juveniles, or by adults on juveniles. It is 

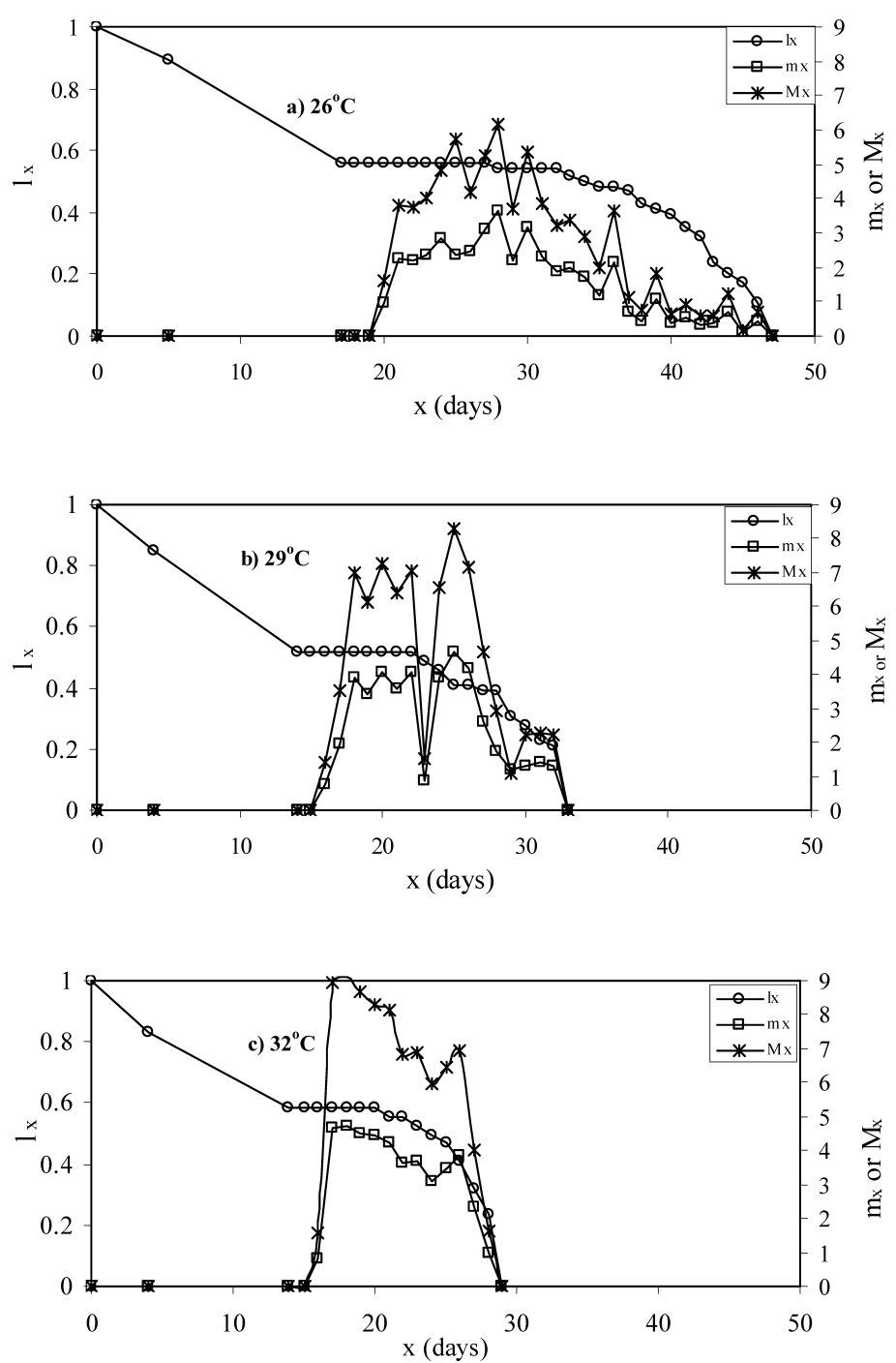

Fig. 1. Reproduction and survival curves of Orius niger at three different temperatures (a: $26^{\circ} \mathrm{C}$, b: $29^{\circ} \mathrm{C}$ and c: $32^{\circ} \mathrm{C}$ ) on a diet of pollen and eggs of $E$. kuehniella. $l_{x}=$ survival of females until age $x ; m_{x}=$ number of female offspring produced at age $x$; and $M_{x}=$ total number of offspring (=number of eggs) produced at age $x$ (days).

therefore advisable to attempt to reduce cannibalism in mass rearing, for example by providing hiding places for juveniles (Van den Meiracker, 1994). Furthermore, mass rearing of $O$. niger is best done at temperatures around $32^{\circ} \mathrm{C}$, although it is possible that growth rates would increase even more with higher temperatures.

In conclusion, the predatory bug $O$. niger can easily be reared on a diet of E. kuehniella eggs and pollen, and is therefore a possible candidate for mass releases for biological control of thrips species such as T. tabaci and F. occidentalis. Because of its adaptation to varying climates in its area of origin, we expect that it will be efficient in a broader range of climatic conditions than the other species of Orius investigated so far.

\section{ACKNOWLEDGEMENTS}

We wish to thank the Agricultural Research and Education Organization of Iran for financial support and especial thank to Prof. W. M. Sabelis, Dr. A. Janssen, University of Amsterdam, The Netherlands and Dr. R. Laughlin for their comments on manuscript.

\section{REFERENCES}

Akramovskaya, E. G. (1978) The biology of some predatory bugs of the family Anthocoridae in the conditions of the Ararat valley in Armenia. Biol. Zh. Armenii 31: 959964.

Alauzet, C., D. Dargagnon and J. C. Malausa (1994) Bionomics of a polyphagous predator: Orius laevigatus (Het.: Anthocoridae). Entomophaga 39: 33-40. 
Andrewartha, H. G. and L. C. Birch (1954) The Distribution and Abundance of Animals. University of Chicago press, Chicago. $782 \mathrm{pp}$.

Birch, S. (1948) The intrinsic rate of natural increase in insect population. J. Anim. Ecol. 17: 15-26.

Broadbent, A. B., W. R. Allen and R. G. Foottit (1987) The association of Franklieneilla occidentalis (Pergande) (Thysanoptera: Thripidae) with greenhouse crops and the tomato spotted wilt virus in Ontario. Can. Entomol. 119: 501-503.

Carey, J. R. (1982) Demography of twospotted spider mite, Tetranychus urticae Koch. Oecologia 52: 289-295.

Carey, J. R. (1993) Applied Demography for Biologists with Special Emphasis on Insects. Oxford University Press, New York. 206 pp.

Carey, J. R. and R. I. Vargas (1985) Demographic analysis of insect mass rearing: a case study of three tephritids. $J$. Econ. Entomol. 78: 523-527.

Cocuzza, G. E., P. De Clercq, S. Lizzio, M. Van de Veire, L. Tirry, D. Degheele and V. Vacante (1997) Life table and predation activity of Orius laevigatus and Orius albidipennis at three constant temperatures. Entomol. Exp. Appl. 85: 189-198.

Fisher, S., C. Linder and J. Freuler (1992) Biologie et utilization de la punaise Orius majusculus Reuter (Heteroptera, Anthocoridae) dans la lutte contre less thrips Frankliniella occidentalis Perg. et Thrips tabaci Lind. en serre. Rev. Suisse Vitic. Arboric. Hortic. 24: 119-127.

German, T. L., D. E. Ulmann and J. W. Mayer (1992) Tospoviruses: diagnosis, molecular biology, phonology, and vector relationships. Annu. Rev. Phytopathol. 30: 315-348

Havelka, J. and R. Zemek (1999) Life table parameters and oviposition dynamics of various population of the predacious gall-midge Aphidoletes aphidimyza. Entomol. Exp. Appl. 91: 481-484.

Isenhour, D. J. and K. V. Yeargan (1981) Effect of temperature on the development of Orius insidiosus with notes on laboratory rearing. Ann. Entomol. Soc. Am. 74: 114116.

Liedo, P. and J. R. Carey (1994) Mass rearing of Anastrepha (Diptera: Tephritidae) fruit flies: a demographic analysis. J. Econ. Entomol. 87: 176-180.

Loomans, A. J., J. C. van Lentern, M. G. Tommasini, S. Maini and J. Riudavets (1995) Biological Control of Thrips Pests. Wageningen Agricultural University, Wageningen. 201 pp.
Pericart, J. (1972) Hemipteres Anthocoridae, Cimicidae et Microphysidae de l'Ouest Palearctique. Faune de L'Europe et du Bassin Mediterraneen. No.7. Masson et Cie, Paris. 402 pp.

Ramakers, P. M. J. (1978) Possibilities for biological control of Thrips tabaci Lind. (Thysanoptera: Thripidae) in glasshouse. Med. Fac. Landbouw. Rijksuniv. Gent. 43: 463-469.

Royer, T. A., J. V. Edelson and B. Catwright (1986) Damage and control of Thrips tabaci Lindeman on spring onions. J. Rio Grande Valley Hortic. Soc. 39: 69-74.

Sabelis, M. W. and P. C. J. Van Rijn (1997) Predation by insects and mites. In Thrips as Crop Pests (T. Lewis ed.). CABI, London, pp. 259-354.

Tommasini, M. G. and G. Nicoli (1993) Adult activity of four Orius species reared on two preys. IOBC/WPRS Bull. 16: 181-184.

Tommasini, M. G. and G. Nicoli (1994) Pre-imaginal activity of four Orius species reared on two prey. IOBC/WPRS Bull. 17: 237-241.

Van de Veire, M. and D. Degheele (1992) Biological control of the western flower thrips, Frankliniella occidentalis (Pergande) (Thysanoptera: Thripidae), in glasshouse sweet peppers with Orius spp. (Hemiptera: Anthocoridae). A comparative study between $O$. niger (Wolff) and O. insidiosus (Say). Biocontrol Sci. Tech. 2: 281-283.

Van den Meiracker, R. A. F. (1994) Life history evolution in mass rearing of Orius insidiosus. Proc. Exper. Appl. Entomol. 5: 25-30.

Van den Meiracker, R. A. F. (1999) Biocontrol of western flower thrips by Heteropteran bugs. PhD thesis, University of Amsterdam, The Netherlands. $147 \mathrm{pp}$.

Van den Meiracker, R. A. F. and P. M. J. Ramakers (1991) Biological control of the western flower thrips Frankliniella occidentalis, in sweet pepper, with the anthocorid predator Orius insidiosus. Med. Fac. Landbouwn. Rijksuniv. Gent. 56: 241-249.

Van Rijn, P. C. J. (2002) The impact of supplementary food on a prey-predator interaction. $\mathrm{PhD}$ thesis, University of Amsterdam, The Netherlands. 267 pp.

Yasunaga, T. (1997) The flower bug genus Orius Wolff (Heteroptera: Anthocoridae) from Japan and Taiwan, part III. Appl. Entomol. Zool. 32: 387-394.

Yasunaga, T. and T. Kashio (1993) Taxonomy and identification of Japanese Orius species. Plant Prot. 47: 180-183 (in Japanese). 